\title{
Meiotic Studies in Some Species of Tribe Cichorieae (Asteraceae) from Western Himalayas
}

\author{
Raghbir Chand Gupta, ${ }^{1}$ Henna Goyal, ${ }^{1}$ Vijay Singh, ${ }^{1}$ and Rajesh Kumar Goel ${ }^{2}$ \\ ${ }^{1}$ Department of Botany, Punjabi University, Patiala 147002, India \\ ${ }^{2}$ Department of Pharmaceutical Sciences and Drug Research, Punjabi University, Patiala 147002, India \\ Correspondence should be addressed to Vijay Singh; vijaykataria05@rediffmail.com
}

Received 28 August 2014; Accepted 16 October 2014; Published 13 November 2014

Academic Editor: Jennifer A. Tate

Copyright (c) 2014 Raghbir Chand Gupta et al. This is an open access article distributed under the Creative Commons Attribution License, which permits unrestricted use, distribution, and reproduction in any medium, provided the original work is properly cited.

The present paper deals with meiotic studies in 15 species belonging to 6 genera of the tribe Cichorieae from various localities of Western Himalayas. The chromosome number has been reported for the first time in Hieracium crocatum $(2 n=10)$ and Lactuca lessertiana $(2 n=2 x=16)$. Further, intraspecific variability has been reported for the first time in H. umbellatum $(2 n=2 x=10$ and $2 n=6 x=54)$, Tragopogon dubius $(2 n=2 x=14$ and $2 n=4 x=28)$, and T. gracilis $(2 n=2 x=14)$. The chromosome report of $2 n=2 x=10$ in Youngia tenuifolia is made for the first time in India. Maximum numbers of the populations show laggards, chromosome stickiness, and cytomixis from early prophase to telophase-II, leading to the formation of aneuploid cells or meiocytes with double chromosome number. Such meiotic abnormalities produce unreduced pollen grains and the reduced pollen viability.

\section{Introduction}

The tribe Cichorieae (also known as Lactuceae) encompasses 95 genera and ca. 2500 species, primarily in temperate to subtropical zones of the Northern Hemisphere [1]. Members of the tribe are characterized by very important uniform characteristics, such as homogamous ligulate capitula and the presence of milky latex.

The presently investigated species are also known to have medicinal uses, such as Hieracium crocatum to cure gastric troubles, Lactuca dolichophylla to cure constipation, L. macrorhiza used as an ingredient to cure stomach ache, L. serriola to treat ailments of the urinary tract, and Taraxacum officinale used as diuretic and laxative [2-4].

Chromosome studies are valuable determinants in studying evolution. Many workers have studied the cytology of Indian Asteraceae, including members of tribe Cichorieae. Cytological studies on the family from Lahaul-Spiti area, an ecologically very fragile cold desert area of Western Himalayas, are almost lacking. As an attempt to fill this lacuna, the present investigations have been undertaken.

\section{Materials and Methods}

2.1. Plant Material. Exploratory surveys were made during the years from 2009 to 2013 in selected localities (Table 1) of Himachal Pradesh (Kullu and Lahaul-Spiti Districts). The cytologically worked-out plants were identified using regional floras and compared with the specimens deposited at the Herbarium of Botanical Survey of India, Northern Circle, Dehra Dun. The voucher specimens (Table 1) were deposited in the Herbarium, Department of Botany, Punjabi University, Patiala (PUN).

2.2. Meiotic Studies. For meiotic chromosome counts, unopened floral buds of suitable sizes were fixed in a freshly prepared Carnoy's fixative (mixture of alcohol, chloroform, and glacial acetic acid in a volume ratio $6: 3: 1$ ) for $24 \mathrm{~h}$. These were subsequently transferred to $70 \%$ alcohol and stored in refrigerator at $4^{\circ} \mathrm{C}$ until used for meiotic analysis. Meiocytes were prepared by squashing the developing anthers and stained with acetocarmine (1\%). Chromosome number was determined at diakinesis/M-I/II/A-I/II from freshly prepared slides with light microscope Olympus. 500-600 pollen 


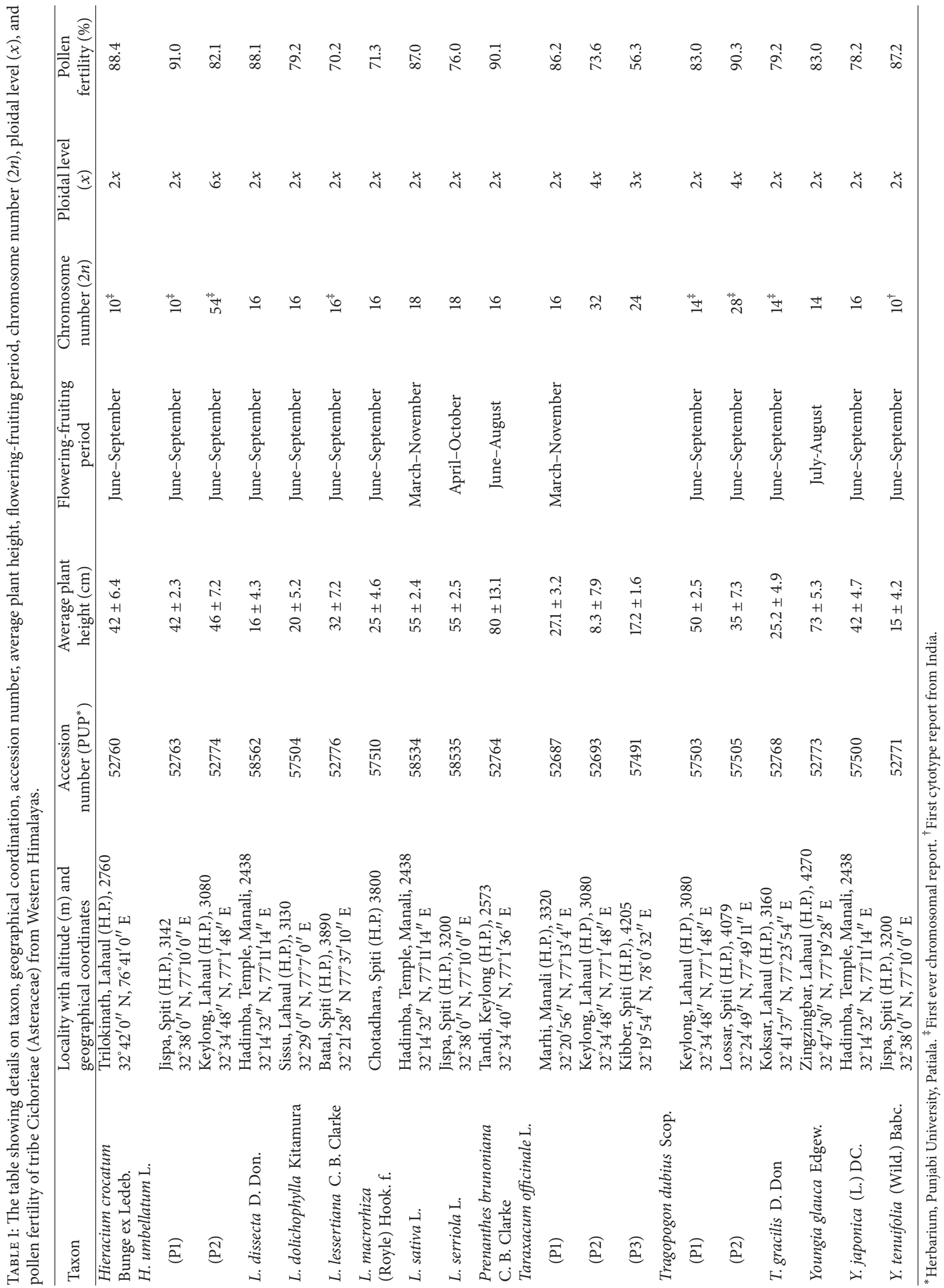




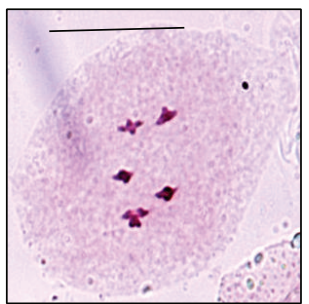

(a)

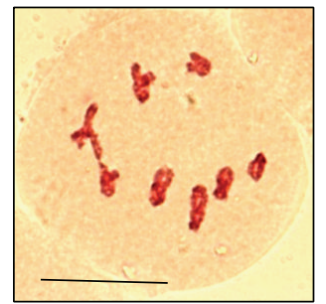

(f)

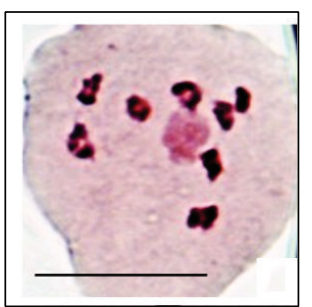

(k)

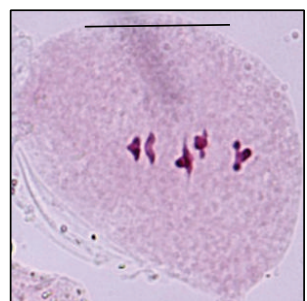

(b)

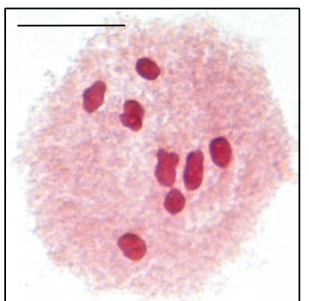

(g)

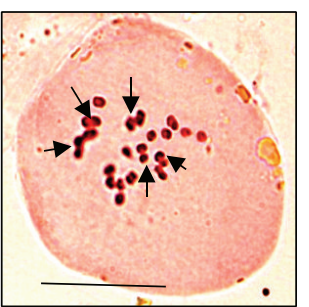

(l)

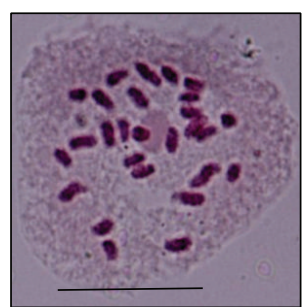

(c)

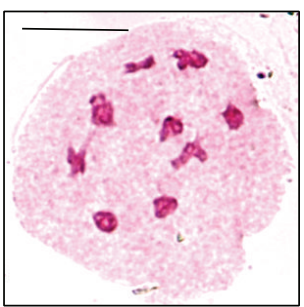

(h)

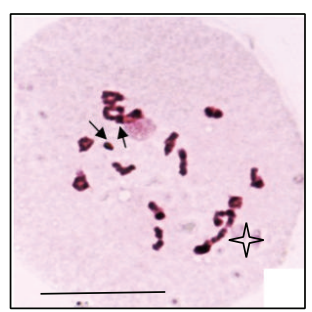

(m)

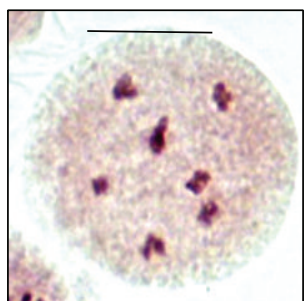

(d)

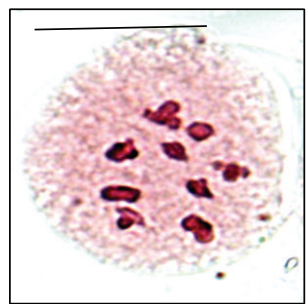

(i)

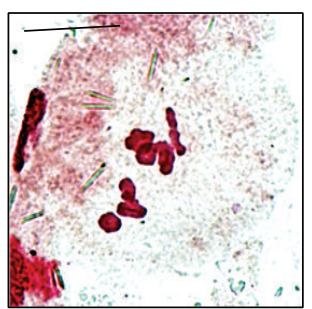

(n)

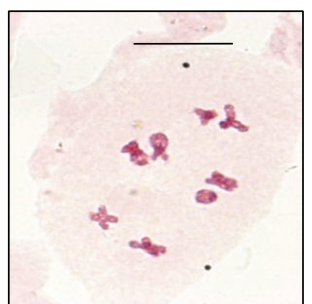

(e)

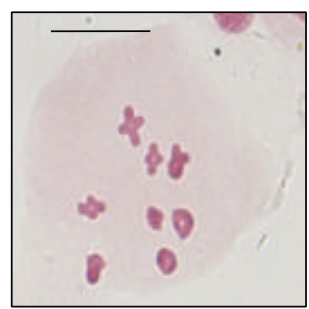

(j)

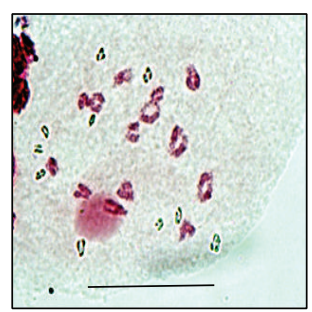

(o)

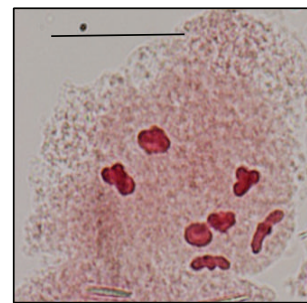

(p)

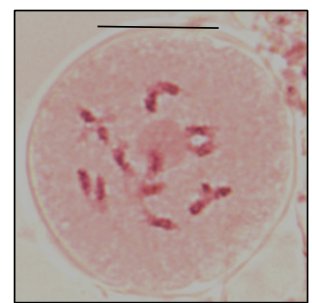

(q)

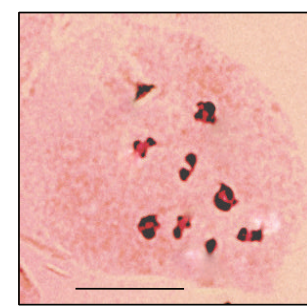

(r)

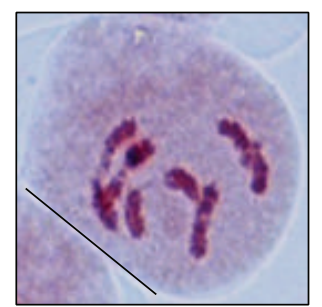

(s)

FIGURE 1: (a) Hieracium crocatum, PMC showing 5II at M-I. (b-c) H. umbellatum: (b) diploid cytotype, PMC showing 5II at M-I, (c) hexaploid cytotype, PMC showing 27II at diakinesis. (d) Lactuca dissecta, A PMC showing 8II at M-I. (e) L. dolichophylla, PMC showing 8II at M-I. (f) L. lessertiana, PMC showing 8II at M-I. (g) L. macrorhiza, PMC showing 8II at M-I. (h) L. sativa, PMC showing 9II at M-I. (i) L. serriola, PMC showing 9II at M-I. (j) Prenanthes brunoniana, PMC showing 8 bivalents at M-I. (k-m) Taraxacum officinale: (k) diploid cytotype, PMC of diploid cytotype showing 8II at diakinesis, (1) triploid cytotype, PMC showing 5II + 14I at M-I (bivalents with arrow), and $(\mathrm{m})$ tetraploid cytotype, PMC showing 1IV + 13II + 2I (univalents with arrow and quadrivalent with star). (n-o) Tragopogon dubius: (n) diploid, PMC showing 7II at M-I, (o) tetraploid cytotype, PMC showing 14II at diakinesis. (p) T. gracilis, PMC showing 7II at M-I. (q) Youngia glauca, PMC showing 7II at diakinesis, (r) Y. japonica, PMC showing 8II at M-I. (s) Y. tenuifolia, A PMC showing 5II at diakinesis. (M-I: metaphase-I, scale: $10 \mu \mathrm{m}, \mathrm{IV}$ : quadrivalent, II: bivalent, I: univalent.)

mother cells were analyzed for meiotic behaviour at different stages, metaphase-I/II (M-I/II), anaphase-I/II (A-I/II), and telophase-I/II (T-I/II).

2.3. Pollen Grain Analysis. Pollen fertility was estimated through stainability tests using glycerol-acetocarmine $(1: 1)$ mixture and aniline blue (1\%). Up to $450-800$ pollen grains were examined for pollen fertility and size frequencies. Wellfilled pollen grains with stained nuclei were taken as apparently fertile while shriveled and unstained pollens were counted as sterile.
2.4. Photomicrographs. Photomicrographs from the freshly prepared desirable slides having clear chromosome counts, dyads, triads, tetrads, and pollen grains were taken with a digital imaging system of Leica QWin.

\section{Results}

\subsection{Chromosome Number}

Hieracium crocatum Bunge ex. Ledeb. The present species revealed the diploid cytotype $(2 n=10$, Figure $1(\mathrm{a}))$, which is a first ever chromosome report for the species. 
H. umbellatum L. Both the cytotypes, $2 n=10$ (Figure 1(b)) and $2 n=54$ (Figure $1(\mathrm{c})$ ), are the new records from the world, although the species is already known to have $2 n=18$ [5] and $2 n=27$ [6] from outside India. Polyploid cytotypes show some enlargement in vegetative and floral characters (Table 2).

Lactuca dissecta D. Don. The present report $(2 n=16$, Figure $1(d))$ is in line with many previous reports from India [7-10] and abroad [11].

L. dolichophylla Kitam. The present chromosome report of $2 n=16$ (Figure $1(\mathrm{e})$ ) is in line with many previous reports from India $[7,8,10,12]$.

L. lessertiana (Wall. ex DC) C. B. Clarke. The present meiotic studies reveal a diploid cytotype $(2 n=16$, Figure $1(f))$ which is a first ever chromosome report for the species.

L. macrorhiza (Royle) Hook. $f$. The present chromosome report of $2 n=16$ (Figure $1(\mathrm{~g})$ ) is already confirmed by many workers $[8,12,13]$ from India. There is no chromosome record from abroad for the species.

L. sativa L. Meiotic analysis of the species reveals the diploid cytotype $(2 n=18$, Figure $1(h))$, which is in conformity with the previous works of Chatterjee and Sharma [14] and Gupta and Gill [15].

L. serriola $L$. The present chromosome report $(2 n=18$, Figure 1(i)) is confirmed by many workers from India $[7,12$, $15,16]$.

Prenanthes brunoniana C. B. Clarke. The present chromosome report of $2 n=16$ (Figure $1(j)$ ) is in conformity to only previous report from Garhwal, Uttarakhand, by Shetty [8].

Taraxacum officinale $L$. The present meiotic investigation revealed three cytotypes, $2 n=2 x=16$ (Figure $1(\mathrm{k})), 2 n=$ $3 x=24$ (Figure $1(\mathrm{l})$ ), and $2 n=4 x=32$ (Figure $1(\mathrm{~m})$ ). Both diploid and tetraploid cytotypes are common and are reported by many workers [17]. Gupta et al. [13], besides triploid cytotype, also reported some other cytotypes, that is, $2 n=26,27,32,38$, and 40. Morphologically, the tetraploids do not show any robust and gigas effect due to polyploidy Table (2), but they certainly show a lot of variation in shape of leaves.

Tragopogon dubius Scop. Both the cytotypes, $2 n=14$ (Figure $1(n)$ ) and $2 n=28$ (Figure $1(\mathrm{o})$ ), are varied cytotypes at world level. The species is reported earlier with $2 n=24$ by Koul and Gohil [18] and Mehra and Remanandan [12] from Kashmir Himalayas. From outside India, the species is known to have $2 n=12,24$, and 36 [5]. Morphologically, tetraploid cytotype does not show any gigas effect as compared to diploid (Table 2).

T. gracilis D. Don. The present chromosome report $(2 n=14$, Figure $1(\mathrm{p})$ ) is a varied chromosome count for the species at world level. Earlier, Mehra and Remanandan [12] reported diploid cytotype with $2 n=12$ from the Western Himalayas.
Youngia glauca Edgew. The present cytological investigation reveals the diploid cytotype $(2 n=14$, Figure $1(\mathrm{q}))$, which is a varied chromosome report. Earlier, there is a maiden cytological report of $2 n=16$ [19] from Kinnaur valley.

Y. japonica (L.) DC. The present chromosome report $(2 n=$ 16, Figure $1(r)$ ) confirms the earlier reports from different localities of India and abroad [20].

Y. tenuifolia (Wild.) Babcock and Stebbins. This chromosome report of $2 n=10$ (Figure $1(\mathrm{~s})$ ) is for the first time reported from India. The same number is frequently reported from abroad [21, 22].

3.2. Meiotic Abnormalities. Meiotic abnormalities have been recorded in almost all the studied populations of different species in the form of cytomixis, chromatin stickiness, unoriented bivalent, bridges, laggards, or multipolarity at different stages of meiosis (Tables 3 and 4, Figures 2(a)-2(k)). From the data, triploid cytotype of Taraxacum officinale shows the highest percentage of chromatin transfer from prophase-I to telophase-II (Table 2, Figure 2(a)). Cytomixis usually led to the formation of pollen mother cells (PMCs) with different chromosome numbers and even empty PMCs in some cases (Figure 2(b)), as is evident in hexaploid cytotype of Hieracium umbellatum. Chromatin stickiness (partial or often complete clumping of bivalents) is found in 16.28 per cent of PMCs and unoriented bivalents were seen in 13.79 per cent of PMCs of tetraploid cytotype of T. officinale (Table 3, Figure 2(c)). The present investigation also reveals abnormal meiosis in the form of chromosomal laggards (maximum in triploid cytotype of $T$. officinale) and bridges (maximum percentage in tetraploid cytotype of $H$. umbellatum) at anaphase-I/II and telophase-I/II (Figures 2(e)-2(f)). These meiotic abnormalities led to the abnormal microsporogenesis and the formation of heterogeneous sized pollen grains (Table 4, Figures 2(g)$2(\mathrm{k})$ ) and also affect pollen viability (Table 1).

\section{Discussion}

\subsection{Chromosome Number}

4.1.1. Tribe Cichorieae. The ancestral basic numbers in the tribe are $x=4,5$, and 9, as suggested by Turner et al. [23]. But Stebbins et al. [24] proposed $x=9$ as the base number for Cichorieae (Asteraceae in general), which is supported by Tomb et al. [25], with the other numbers $(x=3-9)$ derived through phylogenetic reduction through chromosomal aberrations, particularly translocation.

Hieracium L. About 360 species are cytologically known with 94 species being diploid and 152 triploid and 149 species are tetraploid and rarely possess aneuploidy (7 spp.). The genus forms agamic complex and is considered monobasic on $x=$ 9. But, the present study reveals another cytotype $(2 n=10)$, suggesting a new base number $(x=5)$ in the genus.

Lactuca L. A total of 150 species are known taxonomically, of which chromosome numbers for 87 species overall and 14 species from India are known. The chromosome number in 


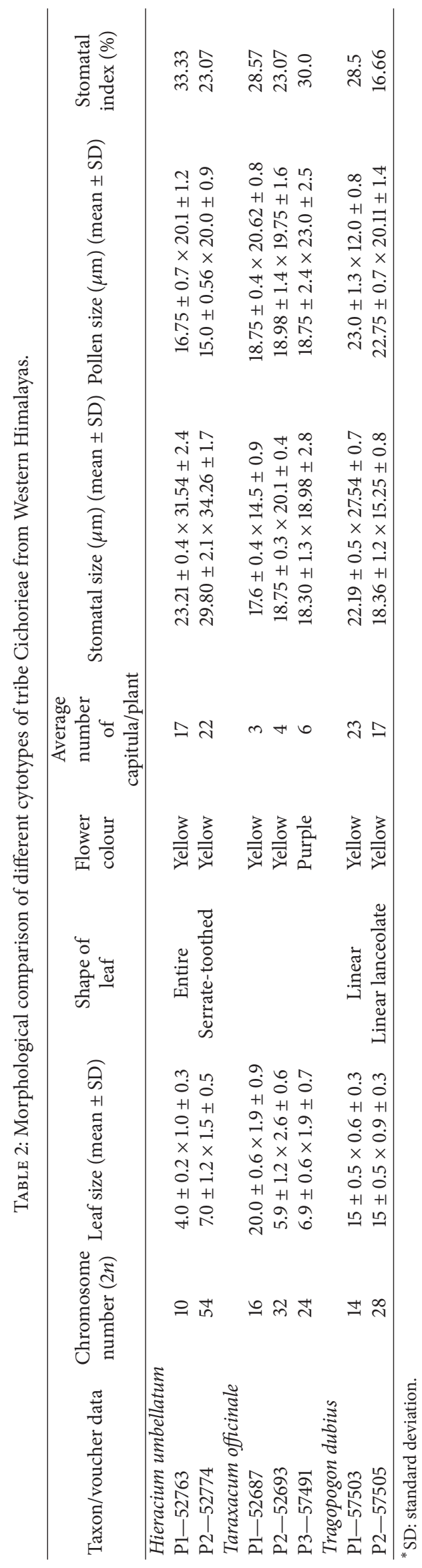


TABLE 3: Data on cytomixis and meiotic course in the studied populations of tribe Cichorieae from Western Himalayas.

\begin{tabular}{|c|c|c|c|c|c|c|}
\hline \multirow{2}{*}{$\begin{array}{l}\text { Accession } \\
\text { number }\end{array}$} & \multicolumn{2}{|c|}{ Cytomixis } & \multicolumn{4}{|c|}{ Meiotic course } \\
\hline & $\begin{array}{c}\text { PMCs } \\
\text { involved (\% } \\
\text { age) }\end{array}$ & $\begin{array}{l}\text { Number of } \\
\text { PMCs } \\
\text { involved (\%) }\end{array}$ & $\begin{array}{c}\text { PMCs with } \\
\text { chromosomal } \\
\text { stickiness at M-I } \\
(\%)\end{array}$ & $\begin{array}{c}\text { PMCs with } \\
\text { unoriented } \\
\text { bivalents at M-I } \\
(\%)\end{array}$ & $\begin{array}{c}\text { PMC with bridges } \\
\text { (at A-I, II/T-I, II) } \\
(\%)\end{array}$ & $\begin{array}{l}\text { PMCs with } \\
\text { laggards (at A-I, } \\
\text { II/T-I, II) (\%) }\end{array}$ \\
\hline 52760 & $0.8(10 / 125)$ & $1-2$ & $3.10(4 / 129)$ & $7.20(9 / 125)$ & $10.08(12 / 114)$ & $10.56(13 / 123)$ \\
\hline 52763 & $3.96(8 / 126)$ & $1-2$ & $5.50(6 / 109)$ & $2.30(3 / 130)$ & $4.31(6 / 139)$ & $1.55(2 / 129)$ \\
\hline 52774 & $11.71(13 / 111)$ & $2-4$ & $11.57(14 / 121)$ & $13.79(16 / 118)$ & $26.95(38 / 141)$ & $10.44(14 / 134)$ \\
\hline 52764 & $2.4(3 / 125)$ & $1-2$ & $4.0(5 / 125)$ & $-1-$ & $4.0(5 / 125)$ & $-1-$ \\
\hline 58562 & $5.4(6 / 111)$ & $1-2$ & $3.17(4 / 126)$ & $2.70(3 / 111)$ & $-1-$ & $-1-$ \\
\hline 57504 & $-1-$ & 0 & $0.82(1 / 121)$ & $1.80(2 / 111)$ & $4.50(5 / 111)$ & $0.82(1 / 121)$ \\
\hline 52776 & $-1-$ & 0 & $1.66(2 / 120)$ & $-1-$ & $-1-$ & $-1-$ \\
\hline 57510 & $2.77(4 / 144)$ & $1-2$ & $3.47(5 / 144)$ & $2.0(3 / 144)$ & $-1-$ & $-1-$ \\
\hline 58534 & $-1-$ & 0 & $-1-$ & $-1-$ & $-1-$ & $-1-$ \\
\hline 58535 & $1.0(1 / 97)$ & $1-2$ & $11.34(11 / 97)$ & $6.1(6 / 97)$ & $7.21(7 / 97)$ & $2.06(2 / 97)$ \\
\hline 52687 & $4.35(5 / 144)$ & $2-3$ & $5.50(6 / 109)$ & $8.39(11 / 131)$ & $3.84(8 / 130)$ & $10.08(12 / 114)$ \\
\hline 52693 & $1.78(2 / 112)$ & $1-2$ & $7.20(9 / 125)$ & $-1-$ & $3.10(4 / 129)$ & $3.84(8 / 130)$ \\
\hline 57491 & $29.91(35 / 117)$ & $2-6$ & $16.28(21 / 129)$ & $13.79(16 / 116)$ & $12.5(17 / 136)$ & $10.44(14 / 134)$ \\
\hline 57503 & $2.43(3 / 123)$ & $1-2$ & $2.30(3 / 130)$ & $-1-$ & $-1-$ & $-1-$ \\
\hline 57505 & $1.72(2 / 160)$ & $1-2$ & $1.37(2 / 145)$ & $2.38(3 / 126)$ & $1.16(2 / 125)$ & $3.25(4 / 123)$ \\
\hline 52768 & $-1-$ & 0 & $-1-$ & $-1-$ & $-1-$ & $-1-$ \\
\hline 52773 & $0.88(1 / 113)$ & $1-2$ & $3.53(4 / 113)$ & $1.76(2 / 113)$ & $5.30(6 / 113)$ & $1.76(2 / 113)$ \\
\hline 57500 & $-1-$ & 0 & $-1-$ & $-1-$ & $-1-$ & $-1-$ \\
\hline 57771 & $1.61(2 / 124)$ & $1-2$ & $1.62(2 / 123)$ & $-1-$ & $-1-$ & $-1-$ \\
\hline
\end{tabular}

Figures in parenthesis denote observed number of abnormal PMCs in the numerator and total PMCs observed in the denominator.

TABLE 4: Data on abnormal microsporogenesis on different accession of tribe Cichorieae from Western Himalayas.

\begin{tabular}{|c|c|c|c|c|c|c|c|}
\hline \multirow{2}{*}{ Taxon/accession numbers } & \multirow{2}{*}{$\begin{array}{l}\text { Monads } \\
\text { WM (\%) }\end{array}$} & \multicolumn{2}{|c|}{ Dyads } & \multicolumn{2}{|c|}{ Triads } & \multicolumn{2}{|c|}{ Tetrads } \\
\hline & & WM (\%) & WMN (\%) & WM (\%) & WMN (\%) & WM (\%) & WMN (\%) \\
\hline 58533 & $-1-$ & $-1-$ & $0.97(1 / 103)$ & $-1-$ & $2.91(3 / 103)$ & $-1-$ & $96.11(99 / 103)$ \\
\hline 52760 & $2.75(3 / 109)$ & $0.91(1 / 109)$ & $2.75(3 / 109)$ & $-1-$ & $2.75(3 / 103)$ & $-1-$ & $90.82(99 / 109)$ \\
\hline 52763 & $-1-$ & $-1-$ & $1.80(2 / 111)$ & $2.70(3 / 111)$ & $1.80(2 / 111)$ & $3.60(4 / 111)$ & $90.09(100 / 111)$ \\
\hline 52774 & $1.5(2 / 130)$ & $0.76(1 / 130)$ & $2.30(3 / 130)$ & $3.07(4 / 130)$ & $2.3(3 / 130)$ & $3.8(5 / 130)$ & $86.15(112 / 130)$ \\
\hline 52764 & $-1-$ & $-1-$ & $1.6(2 / 120)$ & $-1-$ & $-1-$ & $-1-$ & $98.3(118 / 120)$ \\
\hline 58562 & $-1-$ & $-1-$ & $-1-$ & $-1-$ & $-1-$ & $-1-$ & $100(123 / 123)$ \\
\hline 57504 & $-1-$ & $0.95(1 / 105)$ & $-1-$ & $1.90(2 / 105)$ & $2.8(3 / 105)$ & $1.90(2 / 105)$ & $92.38(97 / 105)$ \\
\hline 52776 & $-1-$ & $-1-$ & $1.66(2 / 121)$ & $-1-$ & $4.13(5 / 121)$ & $-1-$ & $95.04(115 / 121)$ \\
\hline 57510 & $-1-$ & $0.80(1 / 124)$ & $1.61(2 / 124)$ & $-1-$ & $4.03(5 / 124)$ & $1.61(2 / 124)$ & $91.93(114 / 124)$ \\
\hline 58534 & $-1-$ & $1.05(1 / 95)$ & $-1-$ & $-1-$ & $-1-$ & $-1-$ & $99.2(139 / 140)$ \\
\hline 58535 & $-1-$ & $1.72(2 / 116)$ & $4.31(5 / 116)$ & $2.58(3 / 116)$ & $4.31(5 / 116)$ & $5.17(6 / 116)$ & $81.89(95 / 116)$ \\
\hline 52687 & $-1-$ & $1.5(2 / 130)$ & $0.76(1 / 130)$ & $0.76(1 / 130)$ & $2.30(3 / 130)$ & $1.5(2 / 130)$ & $93.07(121 / 130)$ \\
\hline 52593 & $-1-$ & $-1-$ & $0.8(1 / 125)$ & $2.4(3 / 125)$ & $0.8(1 / 125)$ & $1.6(2 / 125)$ & $94.4(118 / 125)$ \\
\hline 57491 & $2.29(2 / 87)$ & $4.59(4 / 87)$ & $1.14(1 / 87)$ & $2.29(2 / 87)$ & $3.44(3 / 87)$ & $11.49(10 / 87)$ & $72.41(63 / 87)$ \\
\hline 57503 & $-1-$ & $-1-$ & $-1-$ & $-1-$ & $-1-$ & $-1-$ & $100(121 / 121)$ \\
\hline 57505 & $-1-$ & $-1-$ & $0.8(1 / 125)$ & $-1-$ & $1.6(2 / 125)$ & $0.8(125)$ & $96.8(121 / 125)$ \\
\hline 52768 & $1.66(2 / 121)$ & $4.13(5 / 121)$ & $0.82(1 / 121)$ & $4.13(5 / 121)$ & $0.82(1 / 121)$ & $0.82(1 / 121)$ & $87.60(106 / 121)$ \\
\hline 52773 & $-1-$ & $0.86(1 / 115)$ & $2.60(3 / 115)$ & $-1-$ & $2.60(3 / 115)$ & $1.73(2 / 115)$ & $92.17(106 / 115)$ \\
\hline 57500 & $1.66(2 / 121)$ & $0.82(1 / 121)$ & 0 & $0.82(1 / 121)$ & $0.82(1 / 121)$ & $13.22(16 / 121)$ & $82.64(100 / 121)$ \\
\hline 52771 & $-1-$ & $-1-$ & $3.10(4 / 129)$ & $0.75(1 / 129)$ & $6.97(9 / 129)$ & $8.52(11 / 129)$ & $80.60(104 / 117)$ \\
\hline
\end{tabular}

Figures in parenthesis denote observed number of abnormal PMCs in the numerator and total number of PMCs observed in denominator; WMN: without micronuclei, WM: with micronuclei. 


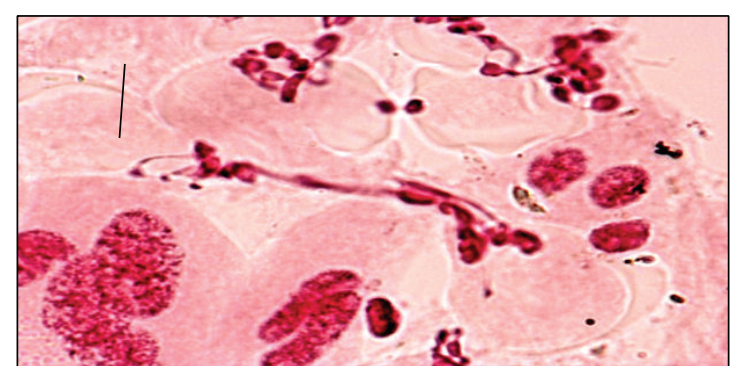

(a)

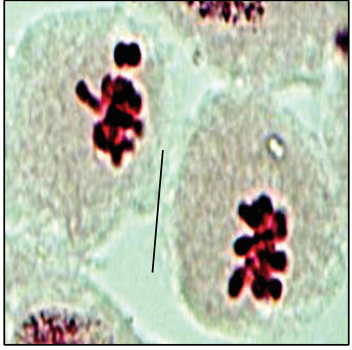

(c)

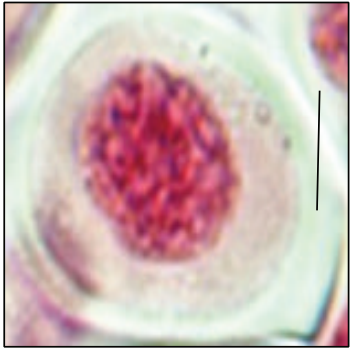

(g)

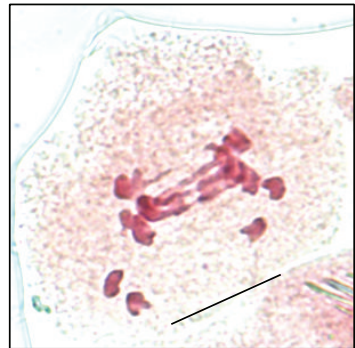

(d)

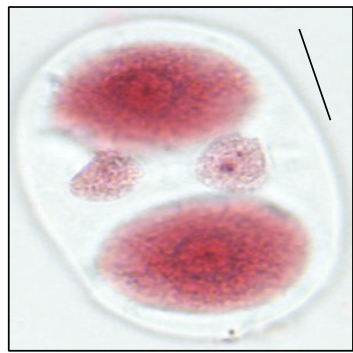

(h)

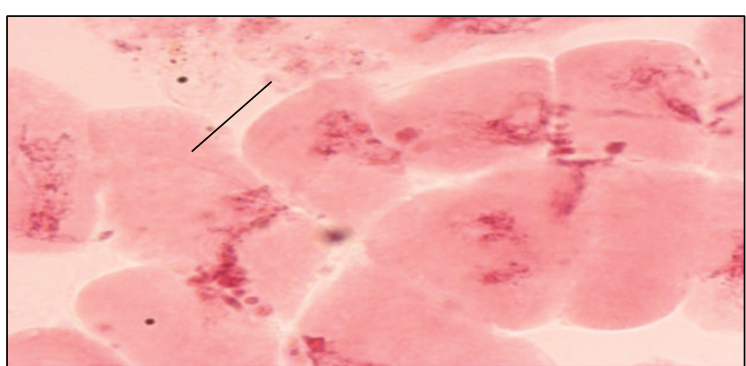

(b)

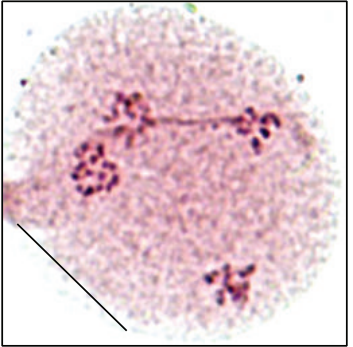

(e)

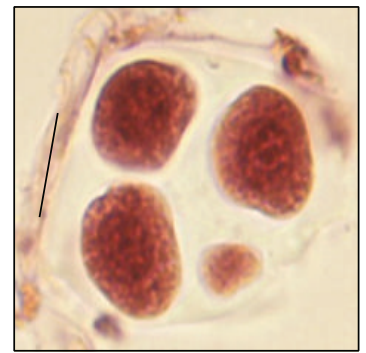

(i)

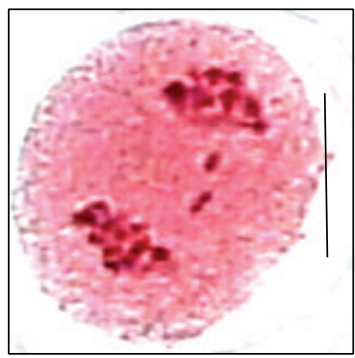

(f)

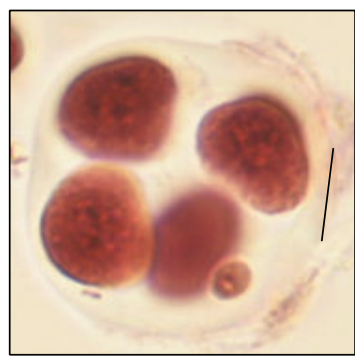

(j)

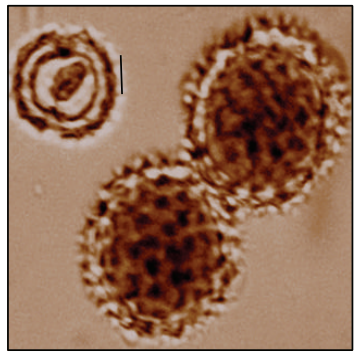

$(\mathrm{k})$

FIgURE 2: (a-b) PMC showing transfer of chromatin material in Taraxacum officinale and Hieracium umbellatum, respectively. (c) PMC at metaphase-I showing chromatin stickiness in tetraploid cytotype of T. officinale. (d) PMC showing late disjunction at anaphase-1 (arrowed). (e) PMC at telophase-II showing chromatin bridges (arrowed). (f) PMC at anaphase-I showing chromatin laggards (arrowed) in triploid cytotype of T. officinale. (g) Monad. (h) Diad with micronuclei. (i) Triad with micronucleus. (j) Tetrad with micronucleus. (k) Heterogeneous sized fertile and sterile (arrowed) pollen grains. (Scale: $10 \mu \mathrm{m}$, IV: quadrivalent, II: bivalent, I: univalent.)

the genus varies in the range of $2 n=10-48$ and is polybasic on $x=5,8,9$, and 17 , of which $x=9$ is the most dominant number.

Prenanthes $L$. Twenty-two species in the genus are known cytotaxonomically, including 1 from India. The most common base number is $x=8$ represented with 19 species, including diploids (16 species) and tetraploids (3 species). However, the intraspecific polyploids are not available in the genus. Besides, $x=9$ is also present in 3 species that are diploid. Hence, the genus is proposed to be dibasic on $x=8$ and 9.

Taraxacum $L$. The genus is very complex, reinforcing the reason of having 347 cytologically (including 10 species from India) worked-out species. The chromosome numbers vary in the range of $2 n=8-64$, the most common of which is $2 n=3 x=24$ (230 spp.) on $x=8$, followed by diploid ( 47 spp.) on the same base number. Genus is reported to have a series of base numbers on $x=4,6,8,9$, and 11, but only $x=8$ 
is known to have well-developed polyploid races $(2 x-6 x)$. Intraspecific polyploidy is also known to occur in $x=9$ and 11 (1 species each).

Tragopogon L. 75 species in the genus are cytologically known, with chromosome number in the range of $2 n=12-36$, almost all based on $x=6$. The overall polyploidy in the genus is $26.6 \%$ (20 spp.), out of which 14 species show intraspecific polyploidy. The variable chromosome number of $2 n=14$ is found in 4 species (including the present data) and $2 n=28$ in only one species (from the present data).

Youngia L. A total of 35 species are taxonomically known, cytology is reported for only 14 species (including 5 from India), with 9 species showing polyploid cytotypes $(3 x, 4 x$, and $6 x$ ). The chromosome numbers reported so far are $2 n=$ $10,15,16,20,24,32$, and 42 , out of which $2 n=10(43.7 \%)$ is the most common followed by $2 n=16(31.2 \%)$. The genus is polybasic ( $x=5,7$, and 8 ), of which $x=5$ is most common.

4.2. Meiotic Abnormality. The phenomenon of inter-PMC migration of chromatin/chromosome between/among the contiguous meiocytes through cytomictic channels is termed as cytomixis (coined by Gates [26]). However, the phenomenon has been reported for the first time in gymnosperms by Arnoldy [27] and subsequently in angiosperms by Koernicke [28]. Since that time, cytomixis has been reported in a large number of plants [29]. Transfer of chromatin or chromosomes may take place through such inter-PMC cytomictic channels [30-32]. Some workers reported cytomixis to be more prevalent in polyploids than their diploid counterparts [33, 34]. Occasionally, either hypoploid meiocytes [35-37] or enucleated meiocytes or meiocytes with a hyperploid number of chromosomes have been reported [30, 37-39]. It is very much clear that the enucleated meiocytes die, but hypo- and hyperploid meiocytes could lead to the formation of gametes with variable chromosome number and size. Cytomixis is considered as a process of evolutionary significance because it results in change in gametic chromosome numbers [30, 40]. Chromosome stickiness also results in the formation of fragmented chromatin. This chromatin stickiness, late or nondisjuncting bivalents, and chromosomal laggards seem to be responsible for chromosomal bridges [41]. All these meiotic abnormalities consequently assert an effect on microsporogenesis, leading to the formation of monads, dyads, triads, or polyads with or without micronuclei, which ultimately produce heterogeneous sized (large and small) fertile pollen grains and reduced pollen fertility. The size difference may be due to the formation of unreduced gametes $(2 n)$, which may produce plants with higher ploidal level through polyploidization (for review, see [42-45]).

As observed in the presently investigated data, the chromatin rearrangement due to meiotic abnormalities is considered the base of inter- or intraspecific diversity. Further, it provides a catalogue for studying different evolutionary trends such as breeding system or polyploidy and hybridization.

\section{Conflict of Interests}

The authors declare that there is no conflict of interests regarding the publication of this paper.

\section{Acknowledgments}

The authors are grateful to the University Grants Commission of New Delhi (DRS SAP III) and I.P.L.S. (DBT) for providing financial assistance. The authors are highly thankful to the Head, Department of Botany, Punjabi University, Patiala, for providing necessary lab facilities during the work.

\section{References}

[1] Z. Shi, X. J. Ge, N. Kilian et al., "Cichorieae," in Flora of China, Z. Y. Wu, P. H. Raven, and D. Y. Hong, Eds., vol. 20-21 of Asteraceae, pp. 195-353, Science Press, Beijing, China, Missouri Botanical Garden Press, St. Louis, Mo, USA, 2011.

[2] M. Howard, Traditional Folk Remedies, Ebury Press, London, UK, 1987.

[3] B. A. Clare, R. S. Conroy, and K. Spelman, "The diuretic effect in human subjects of an extract of Taraxacum officinale folium over a single day," Journal of Alternative and Complementary Medicine, vol. 15, no. 8, pp. 929-934, 2009.

[4] K. N. Singh, "Traditional knowledge on ethnobotanical uses of plant biodiversity: a detailed study from the Indian western Himalaya," Biodiversity: Research and Conservation, vol. 28, pp. 63-67, 2012.

[5] E. A. Nazarova, "Chromosome numbers in the Caucasian representatives of the families Asteraceae, Brassicaceae, Fabaceae, Limoniaceae," Botanicheskii Zhurnal, vol. 69, pp. 972-975, 1984 (Russian).

[6] S. A. Volkova and E. V. Boyko, "Chromosome numbers in some species of Asteraceae from the southern part of the Soviet Far East," Botanicheskii Zhurnal, vol. 71, p. 1693, 1986.

[7] P. N. Mehra, B. S. Gill, J. K. Mehta, and S. S. Sidhu, "Cytological investigations on the Indian Compositae. I. North-Indian taxa," Caryologia, vol. 18, pp. 35-68, 1965.

[8] B. V. Shetty, "IOPB chromosome number reports XIV", in Taxon, vol. 16, pp. 552-571, 1967.

[9] R. C. Gupta, Himshikha, P. Kumar, and R. S. Dhaliwal, "Cytological studies in some plants from cold deserts of India, Lahaul and Spiti (Himachal Pradesh)," Chromosome Botany, vol. 4, no. 1, pp. 5-11, 2009.

[10] S. Bala and R. C. Gupta, "IAPT/IOPB chromosome data 12," in Taxon, K. Marhold, Ed., vol. 60, pp. 1784-1786, 2011.

[11] Z. A. Razaq, A. A. Vahidy, and S. I. Ali, "Chromosome numbers in Compositae from Pakistan," Annals of the Missouri Botanical Garden, vol. 81, no. 4, pp. 800-808, 1994.

[12] P. N. Mehra and P. Remanandan, "IOPB chromosome number reports XXII," Taxon, vol. 18, pp. 433-442, 1969.

[13] R. C. Gupta, B. S. Gill, and R. K. Garg, "Chromosomal conspectus of Western Himalayan Compositae," Aspects of Plant Sciences, vol. 11, pp. 427-437, 1989.

[14] T. Chatterjee and A. K. Sharma, "Cytotaxonomy of cichorieae," Genetica, vol. 40, no. 1, pp. 577-590, 1969.

[15] R. C. Gupta and B. S. Gill, "Cytology of family Compositae of Punjab plains," Proceedings of the National Academy of Sciences, India, Section B, vol. 49, pp. 359-370, 1983.

[16] A. K. Koul, A. Wakhlu, and J. L. Karihaloo, "Chromosome numbers of some flowering plants of Jammu (Western Himalayas) II," Chromosome Information Service (CIS) 20, 1976.

[17] B. S. Gill and R. C. Gupta, "Cytological investigations on the North-West Himalayan Taraxacum officinale complex (Compositae)," in Recent Researches in Plant Sciences, S. S. Bir, Ed., pp. 292-301, Kalyani Publishers, New Delhi, India, 1979. 
[18] A. K. Koul and P. N. Gohil, "Cytotaxonomical conspectus of the flora of Kashmir, I. Chromosome numbers of some common plants," Phyton, vol. 15, pp. 57-66, 1973.

[19] D. Kaur, V. K. Singhal, and K. Marhold, "IAPT/IOPB chromosome data 13," Taxon, vol. 61, pp. 889-902, 2013.

[20] R. C. Gupta, V. Kataria, and A. Mehra, "Cytomorphological studies in some gamopetalous species of Western Himalaya: an attempt to add new or varied cytotypes," Chromosome Botany, vol. 7, pp. 59-65, 2012.

[21] N. V. Stepanov, "Chromosome numbers of some higher plants taxa of the flora of Krasnoyarsk region," Botanicheskii Zhurnal, vol. 79, pp. 135-139, 1994.

[22] E. G. Rudyka, "Chromosome numbers in vascular plants from the southern part of the Russian Far East," Botaničeskij Žhurnal (Moscow \& Leningrad), vol. 80, pp. 87-90, 1995.

[23] B. L. Turner, W. L. Ellis, and R. M. King, "Chromosome numbers in the Compositae IV," American Journal of Botany, vol. 48, no. 3, pp. 216-223, 1961.

[24] G. L. Stebbins, J. K. Jenkins, and M. S. Walters, Chromosomes and Phylogeny in the Compositae, Tribe Cichorieae, vol. 16, University of California Publications in Botany, Berkeley, Calif, USA, 1953.

[25] A. S. Tomb, K. L. Chambers, D. W. Kyhos, A. M. Powell, and P. H. Raven, "Chromosome numbers in the Compositae. XIV. Lactuceae," The American Journal of Botany, vol. 65, pp. 717-722, 1978.

[26] R. R. Gates, "Pollen formation in oenothera gigas," Annals of Botany, vol. 25, no. 4, pp. 909-940, 1911.

[27] W. Arnoldy, "Beiträge zur Morphologie der Gymnospermen. IV. Was sind die "Keimbläschen" oder "Hofmeisters-Körperchen” in der Eizelle der Abietineen?” Flora, vol. 87, pp. 194-204, 1900.

[28] M. Koernicke, Uber ortsveranderung von Zellkarnern S B Niederhein Ges Natur-U Heilkunde Bonn A, 1901.

[29] V. K. Singhal and P. Kumar, "Impact of cytomixis on meiosis, pollen viability and pollen size in wild populations of Himalayan poppy (Meconopsis aculeata Royle)," Journal of Biosciences, vol. 33, no. 3, pp. 371-380, 2008.

[30] E. Falistocco, N. Tosti, and M. Falcinelli, "Cytomixis in pollen mother cells of diploid Dactylis, one of the origins of $2 \mathrm{n}$ gametes," Journal of Heredity, vol. 86, no. 6, pp. 448-453, 1995.

[31] S. R. Mursalimov and E. V. Deineko, "An ultrastructural study of cytomixis in tobacco pollen mother cells," Protoplasma, vol. 248, no. 4, pp. 717-724, 2011.

[32] E. A. Kravets, "Nature, significance, and cytological consequences of cytomixis," Cytology and Genetics, vol. 46, no. 3, pp. 188-195, 2012.

[33] S. Y. A. Semyarkhina and M. S. Kuptsou, "Cytomixis in various forms of sugar beet," Vestsi AN BSSR Ser Biyal, no. 4, pp. 43-47, 1974.

[34] V. K. Singhal, B. S. Gill, and R. S. Dhaliwal, "Status of chromosomal diversity in the hardwood tree species of Punjab state," Journal Cytology and Genetics, vol. 8, pp. 67-83, 2007.

[35] M. Ashraf and R. N. Gohil, "Cytology of legumes of Kashmir Himalaya. V. Cytomixis and chromosome migration in Astragalus subuliformis DC," Nucleus, vol. 37, pp. 119-122, 1994.

[36] T. Morikawa and J. M. Leggett, "Cytological and morphological variations in wild populations of Avena canariensis from the Canary Islands," Genes \& Genetic Systems, vol. 71, no. 1, pp. 1521, 1996.
[37] M. Sheidai, S. Jafari, P. Taleban, and M. Keshavarzi, "Cytomixis and unreduced pollen grain formation in alopecurus L. and catbrosa beauv. (Poaceae)," Cytologia, vol. 74, no. 1, pp. 31-41, 2009.

[38] M. Bellucci, C. Roscini, and A. Mariani, "Cytomixis in pollen mother cells of Medicago sativa L," Journal of Heredity, vol. 94, no. 6, pp. 512-516, 2003.

[39] P. Kumar, V. K. Singhal, and D. Kaur, "mpaired male meiosis due to irregular synapsis coupled with cytomixis in a new diploid cytotype of Dianthus angulatus (Caryophyllaceae) from Indian cold deserts," Folia Geobotanica, vol. 47, no. 1, pp. 59-68, 2012.

[40] Y. Liu, R.-K. Hui, R.-N. Deng, J.-J. Wang, M. Wang, and Z.Y. Li, "Abnormal male meiosis explains pollen sterility in the polyploid medicinal plant Pinellia ternata (Araceae)," Genetics and Molecular Research, vol. 11, no. 1, pp. 112-120, 2012.

[41] S. Kumar, S. M. Jeelani, S. Rani, R. C. Gupta, and S. Kumari, "Cytology of five species of subfamily Papaveroideae from the Western Himalayas," Protoplasma, vol. 250, no. 1, pp. 307-316, 2013.

[42] R. Villeux, "Diploid and polyploid gametes in crop plants: mechanisms of formation and utilization in plant breeding," in Plant Breeding Reviews, J. Janick, Ed., p. 442, AVI Publishing Co. Wesport, Connecticut, Conn, USA, 1985.

[43] F. Bretagnolle and J. D. Thomson, "Gametes with the somatic chromosome number: mechanisms of their formation and role in the evolution of autopolyploid plants," New Phytologist, vol. 129, no. 1, pp. 1-22, 1995.

[44] F. Fatemeh, M. Sheidai, and M. Asadi, "Cytological study the genus Arenaria L. (Caryophyllaceae)," Caryologia, vol. 63, no. 2, pp. 149-156, 2010.

[45] S. M. Jeelani, S. Rani, S. Kumar, S. Kumari, and R. C. Gupta, "Meiotic studies in some members of Caryophyllaceae juss. from the western Himalayas," Acta Biologica Cracoviensia Series Botanica, vol. 53, no. 1, pp. 86-95, 2011. 

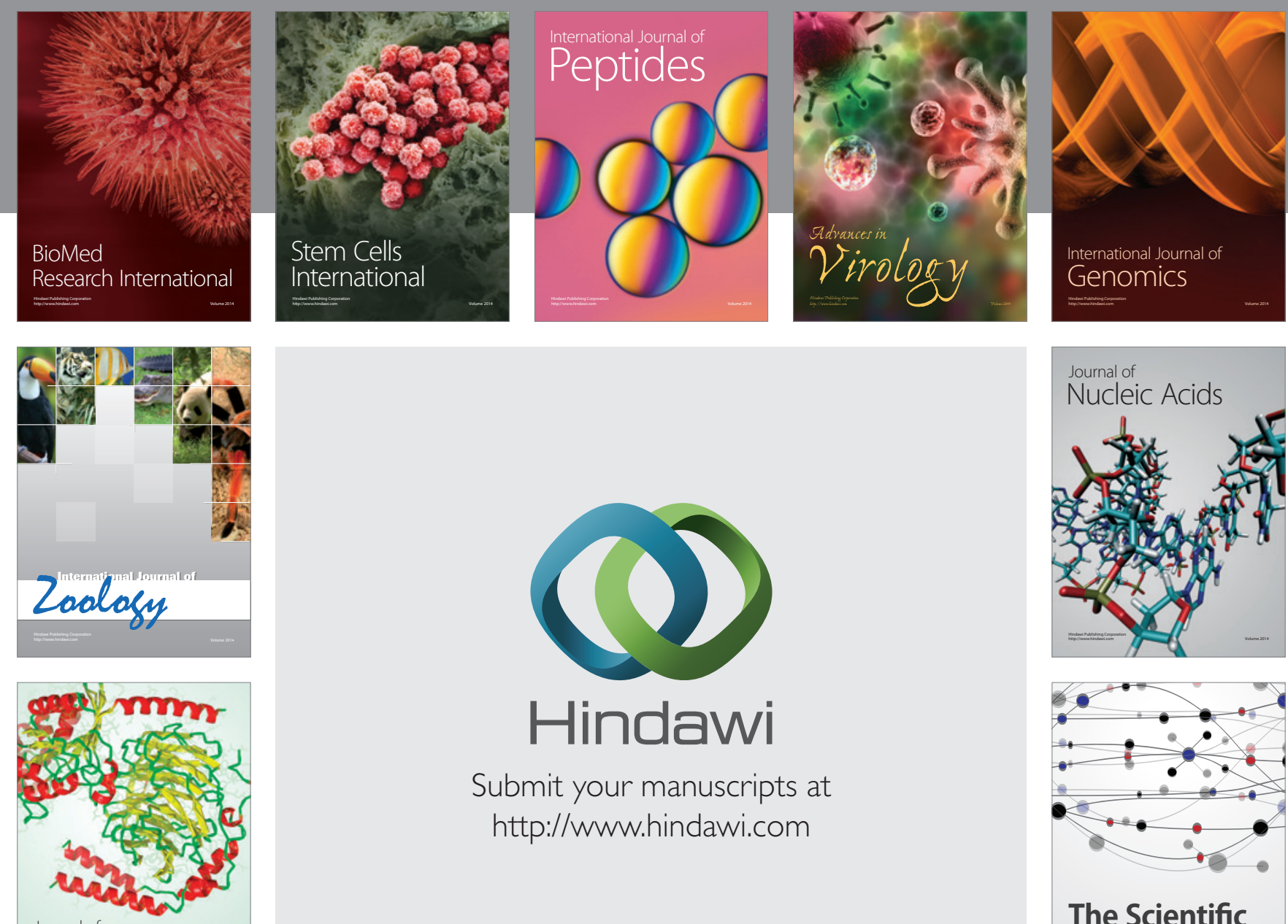

Submit your manuscripts at

http://www.hindawi.com

Journal of
Signal Transduction
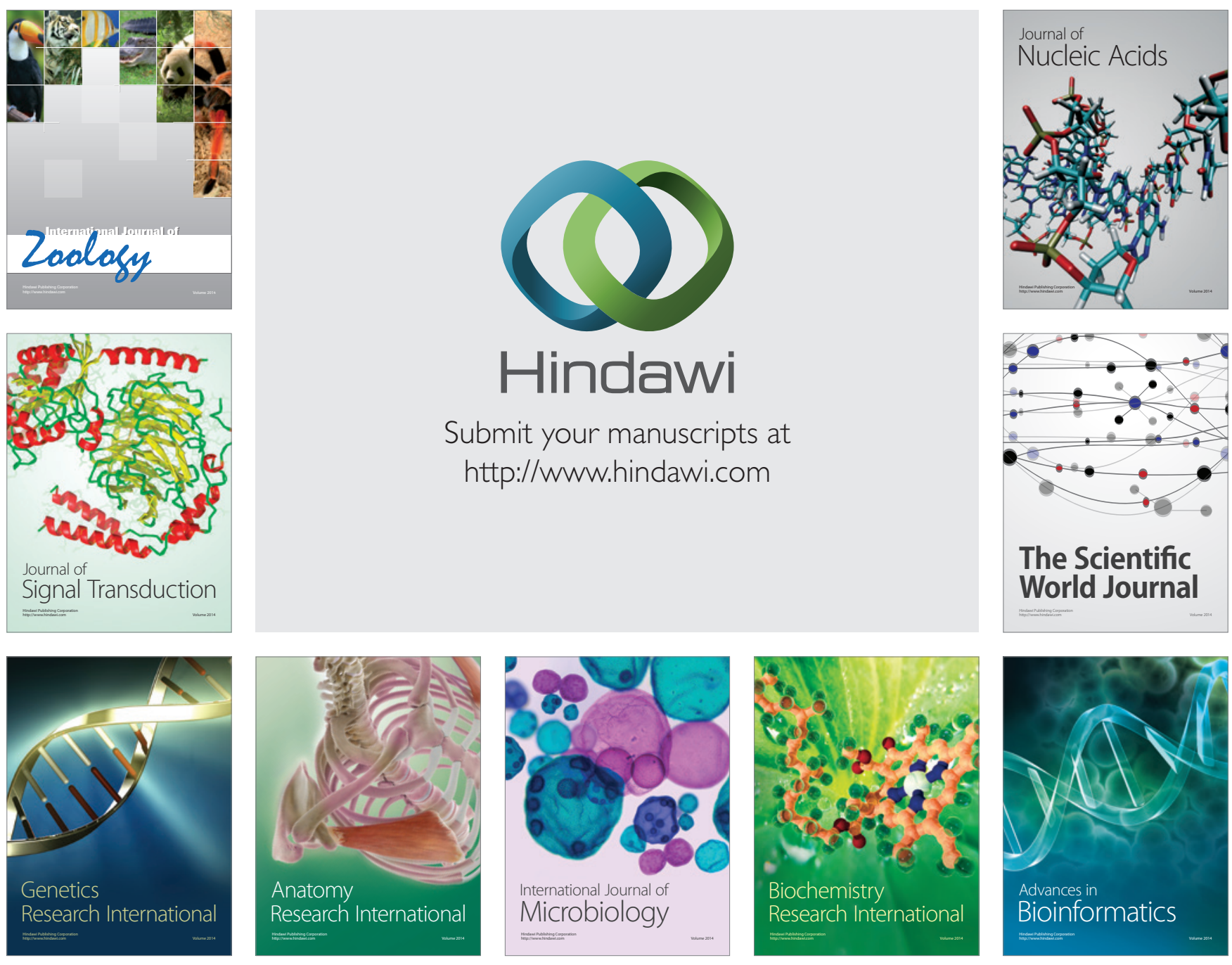

The Scientific World Journal
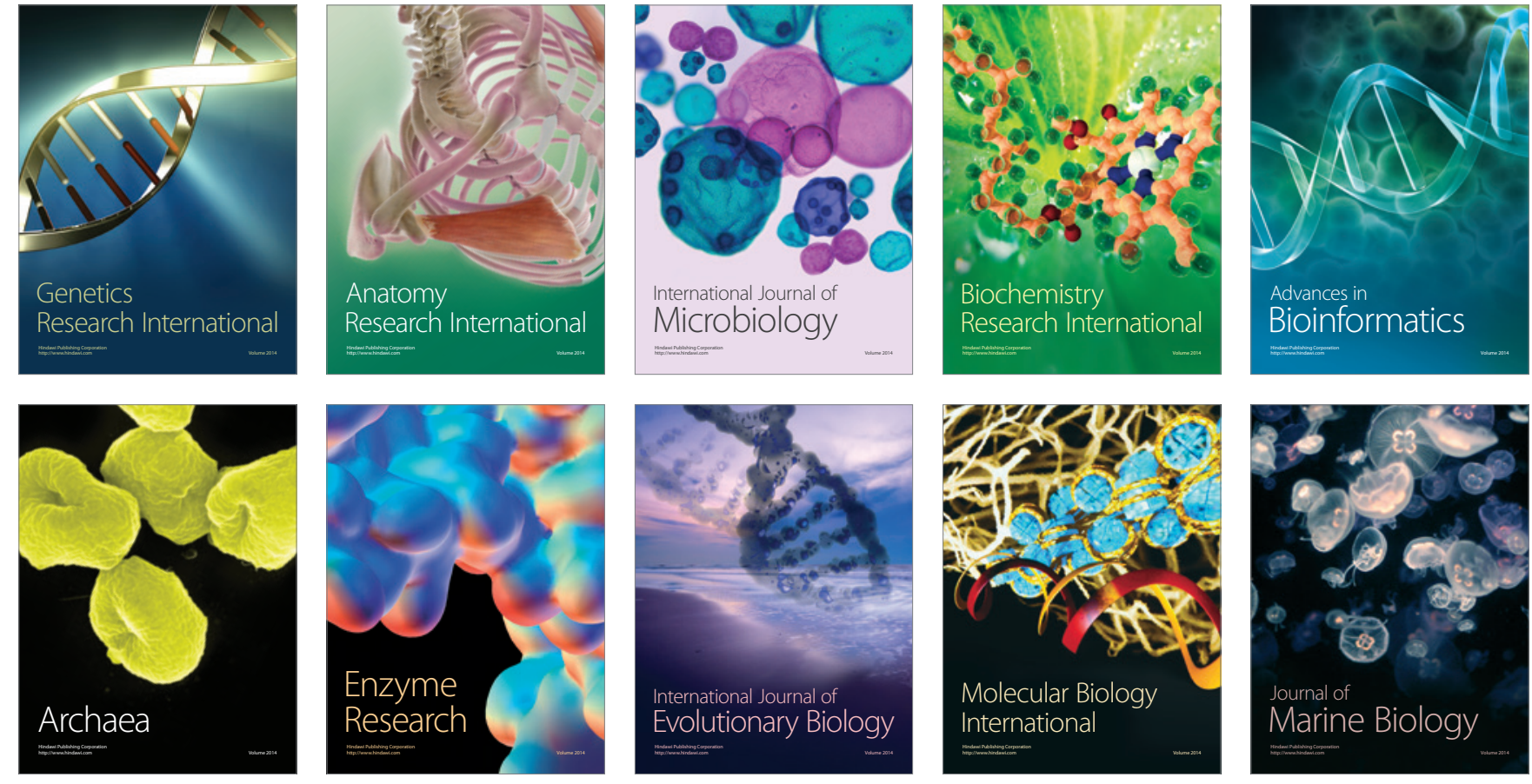